\title{
Embedded system in Arduino platform with Fuzzy control to support the grain aeration decision
}

\author{
Sistema embarcado em plataforma Arduino, com controle Fuzzy \\ para suporte a decisão de aeração de grãos
}

\author{
Albino Szesz Junior ${ }^{I^{*}}$ Marcos Monteiro Junior ${ }^{\mathrm{I}}$ Ariangelo Hauer Dias ${ }^{\mathrm{I}}$ \\ Ivo Mário Mathias ${ }^{\mathrm{I}}$ Giuvane Conti ${ }^{\mathrm{I}}$
}

\section{ABSTRACT}

Aeration is currently the most commonly used technique to improve the drying and storage of grain, depending on temperature and water content of the grain, as of the temperature and relative humidity of the outside air. In order to monitor temperature and humidity of the grain mass, it is possible to have a network of sensors in the cells of both internal and external storage. Use of artificial intelligence through Fuzzy theory, has been used since the 60s and enables their application on various forms. Thus, it is observed that the aeration of grain in function of representing a system of controlled environment can be studied in relation to the application of this theory. Therefore, the aim of this paper is to present an embedded Fuzzy control system based on the mathematical model of CRUZ et al. (2002) and applied to the Arduino platform, for decision support in aeration of grain. For this, an embedded Arduino system was developed, which received the environmental values of temperature and humidity to then be processed in a Fuzzy controller and return the output as a recommendation to control the aeration process rationally. Comparing the results obtained from the graph presented by LASSERAN (1981) it was observed that the system is effective.

Key words: arduino, agriculture, mathematical model, Fuzzy logic, grain aeration.

\section{RESUMO}

A aeração é a técnica mais utilizada para melhorar a secagem e as condições de armazenamento de grãos, dependendo da temperatura e teor de água do grão, e da temperatura e da umidade relativa do ar externo. $O$ controle da aeração depende do monitoramento da temperatura e da umidade da massa de grãos, podendo-se utilizar uma rede de sensores nas células de armazenamento tanto interna como externamente. A utilização de inteligência artificial pela aplicação da teoria Fuzzy vem sendo utilizada desde a década de 60 e pode ser usada em diversos meios.
Assim, observa-se que a aeração de grãos, por ser um sistema de ambiência controlada, pode ser objeto de estudo na aplicação dessa teoria. Diante disso, objetiva-se com este trabalho apresentar um sistema embarcado de controle Fuzzy, baseado no modelo matemático de CRUZ et al. (2002) e aplicados em plataforma Arduino, para suporte a decisão na aeração de grãos. Para tanto, foi desenvolvido um sistema embarcado em Arduino, o qual recebe os valores ambientais: temperatura e umidade para então processar em um controlador Fuzzy e retornar como saída uma recomendação de aeração para controlar o processo de forma racional. Comparandose os resultados obtidos com o gráfico apresentado por LASSERAN (1981), observasse que o sistema é eficaz.

Palavras-chave: arduino, agricultura, modelo matemático, lógica Fuzzy, aeração de grãos.

\section{INTRODUCTION}

Aeration is currently the most widely used technique to improve grain drying and storage conditions. Sets that comprise an aeration system require uniform distribution of the air through the grain mass in a way that will allow it to be homogeneously aerated (HUNG et al., 2009).

For CLOUD \& MOREY (1979.1991) and NAVARRO \& NOYES (2001), aeration is the movement of air through the stored grain mass, thereby maintaining temperatures and water content at safe and homogenous levels, seeking to reduce the activity of insect/pests and fungi, and preventing moisture migration, reducing the rate of deterioration and losses during storage. NAVARRO \& NOYES

\footnotetext{
ISetor de Ciências Agrárias e de Tecnologia, Universidade Estadual de Ponta Grossa (UEPG), 84030-900, Paraná, PR, Brasil. E-mail: albinojr12@gmail.com. "Correspondig author.
} 
(2001) pointed out the importance of uniform distribution of airflow within the grain mass and its constant monitoring to ensure the quality of the grains. WEBER (2005) mentioned that there cannot be storage without reducing the original harvest moisture to a safe moisture level. This proved the importance of monitoring and controlling grain storage.

LASSÉRAN (1981) and SILVA (1995) stated that the aeration is always possible when the outdoor air temperature is lower than that of the grain mass. What is generally reported is that most researchers recommend aeration using the temperature difference between the air and the mass of grains as a criterion.

The aeration depends on the temperature and grain moisture content, as well as temperature and relative air humidity of the external environment. The monitoring of the grain mass temperature can have a network of temperature sensors arranged in a regular manner in the storage cells, and for monitoring the external environment. With this sensor network, the drying operation and storage maintenance at farms can be done in a more rational manner.

Another concern for farmers is the electrical consumption required to perform the aeration process. The high price of electricity is a major factor in rising operating costs. As a result, efforts to develop new technologies that make possible to improve the aeration systems in silos in order to rationalize the use of electricity are important.

In the 1960s, Lofti A. ZADEH (1965), working with artificial intelligence suggested an alternative set theory, Fuzzy set theory, where the passage of true to false was gradual and not abrupt. Thus, it was possible to foresee the establishment of solutions, at a theoretical level, through the interpretation of non-quantitative phenomena, looking for types of inference from theoretical information.

Therefore, the computational structure for Fuzzy Inference Systems is based on the concepts of fuzzy theory and employs the inference process called approximate reasoning, which derives conclusions from a set of fuzzy rules and known facts.

Normally, a fuzzy system executes steps i, ii, and iii. (i) Fuzzification: Mapping step of the actual values of the input and output variables in fuzzy sets. (ii) Inference: Determines the control measures that should be employed according to the rules laid down in the rule base. (iii) Defuzzification: Determines a numerical output from the fuzzy set output obtained in the inference step. In other words, it reflects the linguistic value obtained as a result into a discrete value that represents it better.
Knowing this, and based on the analysis of CRUZ et al. (2002) results, there is a wide range of possibilities for applying Fuzzy theory, where grain aeration can be the subject study and application of this theory, since it represents a system with a controlled environment. In LOPES et al. (2006) a simulation model for the aeration of stored grain was developed, proving the importance of monitoring and controlling stored grain aeration.

Therefore, this study seeks to present a fuzzy control system based on CRUZ et al. (2002) mathematical model based on Arduino, as support for decision making in the grain aeration process, in order to execute the aeration in a rational manner, controlling the aeration time required for a certain grain mass to reach the appropriate storage conditions. For this purpose, it was developed a computer program, based on Arduino, used for storage, processing, and control of data collected by the data acquisition system, simulating the use of temperature and humidity sensors for data acquisition.

\section{MATERIALS AND METHODS}

To automate aeration control, the use of sensors was simulated to monitor the temperature of the grain mass (Tgrain), room temperature (Tair), with measurements ranges between $-10^{\circ} \mathrm{C}$ and $60^{\circ} \mathrm{C}$ and relative humidity (RH) of $10 \%$ to $99 \%$, resolution $0.1^{\circ} \mathrm{C}$ and $\pm 0,1^{\circ} \mathrm{C}$ and $1 \% \mathrm{RH}$.

Considering the difference between grain and air temperature, as the result of Tgrain operation - Tair and relative humidity $\mathrm{RH}$, there are the two conditions that must be combined to produce the event, which will be responsible for the action to be taken by the aeration system.

An instance of environmental conditions for the rational execution of the aeration can be described by conditions. One condition for the difference between grain mass and ambient air temperature (Condition 1), and one for the relative humidity (Condition 2). The solution to the problem was to use a linguistic strategy for the control using fuzzy logic, defining a linguistic variable for each characteristic of the process.

A linguistic variable is composed of a number of linguistic terms that describe the linguistic interpretations of the different characteristics that are being modeled, as well as related functions of pertinence $\mu(\mathrm{x})$.

For the creation of sets and fuzzy terms for the rational execution process for grain aeration, the nomenclature showed in table 1 was 
Table 1 - Nomenclature of sets and fuzzy terms for rational conduct of aeration.

\begin{tabular}{|c|c|c|c|}
\hline Fuzzy set & Linguistic variable & Linguistic term & Value \\
\hline \multirow{11}{*}{$\begin{array}{l}\text { Temperature difference between the } \\
\text { grain mass and the ambient air } \\
\text { (external) }{ }^{\circ} \mathrm{C}\end{array}$} & Minimum & Minimum & 0 \\
\hline & Too Small & TS & 1 \\
\hline & Really Small & $\mathrm{RS}$ & 2 \\
\hline & Little & Little & 3 \\
\hline & Little Bit & LB & 4 \\
\hline & Average & Average & 5 \\
\hline & Little Big & LB & 6 \\
\hline & Big & Big & 7 \\
\hline & Very Big & VB & 8 \\
\hline & Very Large & VL & 9 \\
\hline & Maximum & Maximum & 10 \\
\hline \multirow{15}{*}{$\begin{array}{l}\text { Ambient relative humidity (external) } \\
\text { R.H.\% }\end{array}$} & Minimum & Minimum & 30 \\
\hline & Very Low & VL & 35 \\
\hline & Well Low & WL & 40 \\
\hline & Low & Low & 45 \\
\hline & Nearly Low & NL & 50 \\
\hline & Little Low & LL & 55 \\
\hline & Very Slightly Lower & VSL & 60 \\
\hline & Average & Average & 65 \\
\hline & Very Little High & VLH & 70 \\
\hline & Little High & LH & 75 \\
\hline & Almost High & $\mathrm{AH}$ & 80 \\
\hline & High & High & 85 \\
\hline & Well High & WH & 90 \\
\hline & Very High & $\mathrm{VH}$ & 95 \\
\hline & Maximum & Maximum & 100 \\
\hline \multirow{4}{*}{ Rational execution of aeration } & Possible Care & $\mathrm{PC}$ & 0 \\
\hline & Recommended & $\mathrm{R}$ & 1 \\
\hline & Possible & $\mathrm{P}$ & 2 \\
\hline & Not Recommended & NR & 3 \\
\hline
\end{tabular}

used. Using the rational aeration execution graph proposed by LASSERAN (1981) and the Fuzzy mathematical model proposed by CRUZ et al. (2002) as a basis, the fuzzy sets showed in figure 1 were obtained.

For the temperature difference between the grain mass and the ambient air $(\Delta \mathrm{T}=\mathrm{Tgrain}$ - Tair), a lower limit of $0^{\circ} \mathrm{C}$ and upper limit of $10^{\circ} \mathrm{C}$ was adopted, $1{ }^{\circ} \mathrm{C}$ intervals. For the relative humidity of the ambient air, it was adopted a lower limit of $30 \%$ and upper limit of $100 \%$, with $5 \%$ intervals. For the Defuzzification process for the rational execution of the aeration, values from 0 to 3 were adopted, with an interval of one unit. In this case, it should be noted that the lower and upper limits and the intervals can be changed to other values without compromising the end result of the process.
Since there are eleven linguistic terms for the difference between the grain mass and ambient air temperature, and fifteen for the relative humidity of the ambient air, there will be one hundred sixtyfive different rules available to form a consistent base of rules for the rational execution of the aeration. Thus, the map of rules shown in table 2 represents the entire rule base.

Each combination of a column and a row describes a specific aeration control situation. The action taken by the control was given by the linguistic term of the intersection of the column and the row.

Structure of the fuzzy controller for rational aeration execution process is shown in figure 2, where environmental measurements (real variables) undergo a Fuzzyfication process (events) 


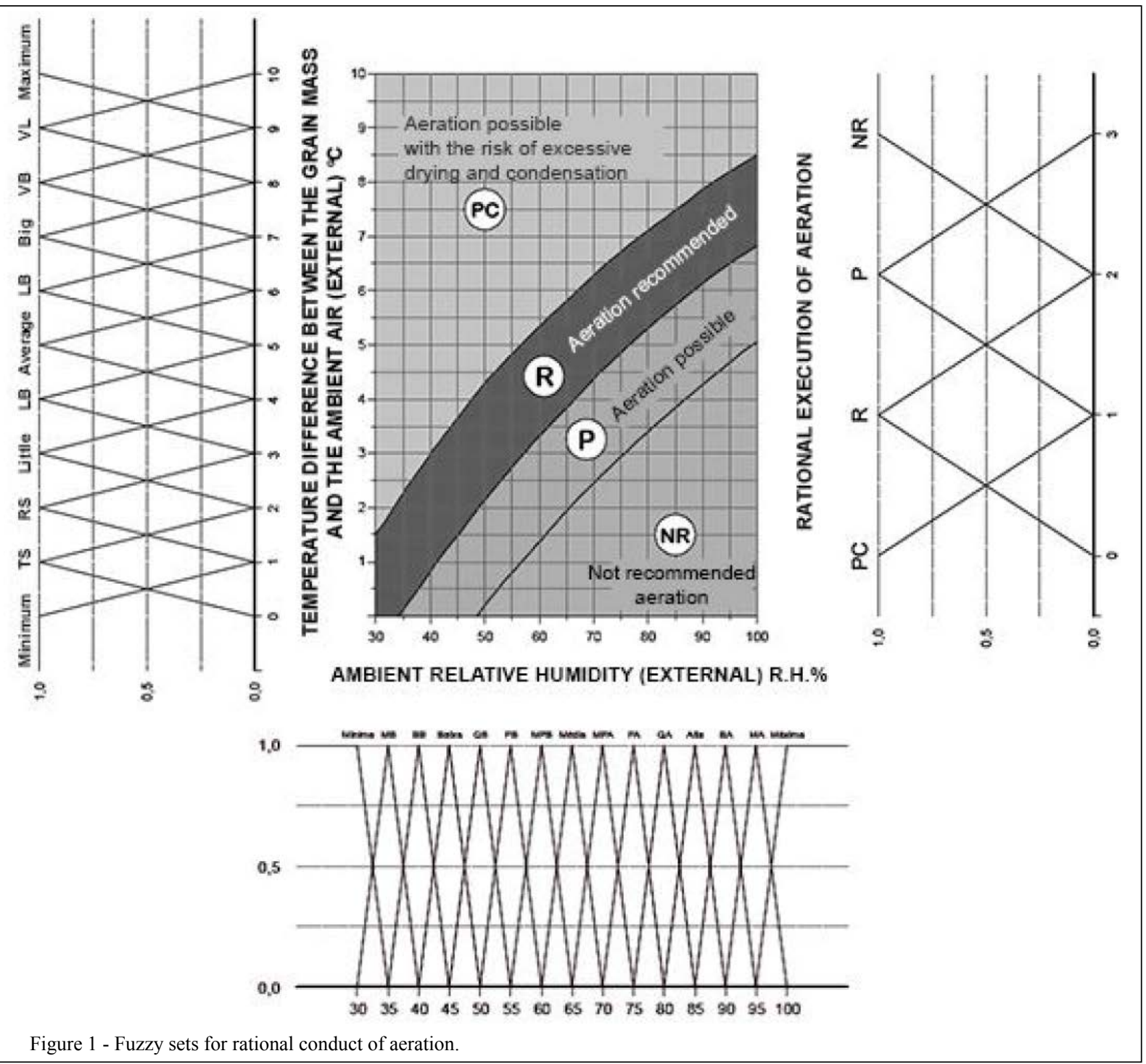

in order to be represented by fuzzy variables and linguistic terms. Through an inference system, using the rule base presented in table 2, an output value was produced representing a fuzzy output variable (conclusions) that will inform the controller which action should be performed.

The data interpretation, shown in figure 2, showed that in the first step all the real variables (sensor signals) have been translated into linguistic variables. For example, a difference between grain and air temperature of $2.6^{\circ} \mathrm{C}$ presented its condition in Rule (1) as "Small" and in regulation (2) as "Very Small" and relative humidity value of $66 \%$ presented its condition in Rule (1) as "Very little high" and in regulation (2) as "Average". Applying
Defuzzification it was obtained a membership value of 2.14 and created the following controller action condition: "The aeration can be executed".

In order to test the designed fuzzy controller, a system was developed in $\mathrm{C}++$ programming language, which was implemented using Arduino's IDE (Integrated Development Environment) version 1.05.

Arduino is an open platform for the development of hardware devices, based on microcontrollers of the Atmel family. This board was developed and perfected by a community, which shares their boards and their codes, and uses an Open Hardware design.

Arduino (OXER \& BLEMINGS, 2009), is an amalgamation of three critical elements: hardware, 
Table 2 - Map rules for rational conduct of aeration.

\begin{tabular}{|c|c|c|c|c|c|c|c|c|c|c|c|c|}
\hline $\mathrm{E}$ & & Minimum & $\begin{array}{l}\text { Too } \\
\text { Small }\end{array}$ & $\begin{array}{l}\text { Really } \\
\text { Small }\end{array}$ & Little & $\begin{array}{l}\text { Little } \\
\text { Bit }\end{array}$ & Average & $\begin{array}{l}\text { Little } \\
\text { Big }\end{array}$ & Big & Very Big & $\begin{array}{l}\text { Very } \\
\text { Large }\end{array}$ & Maximum \\
\hline Minimum & Mi & $\mathrm{R}$ & $\mathrm{R}$ & $\mathrm{PC}$ & $\mathrm{PC}$ & $\mathrm{PC}$ & $\mathrm{PC}$ & $\mathrm{PC}$ & PC & $\mathrm{PC}$ & PC & $\mathrm{PC}$ \\
\hline Very Low & VL & $\mathrm{R}$ & $\mathrm{R}$ & $\mathrm{R}$ & $\mathrm{PC}$ & PC & $\mathrm{PC}$ & $\mathrm{PC}$ & PC & $\mathrm{PC}$ & $\mathrm{PC}$ & $\mathrm{PC}$ \\
\hline Well Low & WL & $\mathrm{P}$ & $\mathrm{R}$ & $\mathrm{R}$ & $\mathrm{R}$ & $\mathrm{PC}$ & $\mathrm{PC}$ & PC & $\mathrm{PC}$ & $\mathrm{PC}$ & $\mathrm{PC}$ & PC \\
\hline Low & Low & $\mathrm{P}$ & $\mathrm{P}$ & $\mathrm{R}$ & $\mathrm{R}$ & $\mathrm{PC}$ & $\mathrm{PC}$ & $\mathrm{PC}$ & $\mathrm{PC}$ & $\mathrm{PC}$ & $\mathrm{PC}$ & PC \\
\hline $\begin{array}{l}\text { Nearly } \\
\text { Low }\end{array}$ & $\mathrm{N}$ & $\mathrm{P}$ & $\mathrm{P}$ & $\mathrm{P}$ & $\mathrm{R}$ & $\mathrm{R}$ & $\mathrm{PC}$ & PC & $\mathrm{PC}$ & $\mathrm{PC}$ & $\mathrm{PC}$ & $\mathrm{PC}$ \\
\hline Little Low & LL & NR & $\mathrm{P}$ & $\mathrm{P}$ & $\mathrm{P}$ & $\mathrm{R}$ & $\mathrm{R}$ & $\mathrm{PC}$ & $\mathrm{PC}$ & $\mathrm{PC}$ & $\mathrm{PC}$ & $\mathrm{PC}$ \\
\hline $\begin{array}{l}\text { Very } \\
\text { Slightly } \\
\text { Lower }\end{array}$ & VSL & NR & NR & $\mathrm{P}$ & $\mathrm{P}$ & $\mathrm{R}$ & $\mathrm{R}$ & PC & $\mathrm{PC}$ & $\mathrm{PC}$ & $\mathrm{PC}$ & $\mathrm{PC}$ \\
\hline Average & Average & NR & NR & $\mathrm{P}$ & $\mathrm{P}$ & $\mathrm{P}$ & $\mathrm{R}$ & $\mathrm{R}$ & $\mathrm{PC}$ & $\mathrm{PC}$ & $\mathrm{PC}$ & $\mathrm{PC}$ \\
\hline $\begin{array}{l}\text { Very Little } \\
\text { High }\end{array}$ & VLH & NR & NR & NR & $\mathrm{P}$ & $\mathrm{P}$ & $\mathrm{R}$ & $\mathrm{R}$ & PC & $\mathrm{PC}$ & $\mathrm{PC}$ & $\mathrm{PC}$ \\
\hline Little High & LH & NR & NR & NR & NR & $\mathrm{P}$ & $\mathrm{P}$ & $\mathrm{R}$ & $\mathrm{R}$ & $\mathrm{PC}$ & $\mathrm{PC}$ & $\mathrm{PC}$ \\
\hline $\begin{array}{l}\text { Almost } \\
\text { High }\end{array}$ & $\mathrm{AH}$ & NR & NR & NR & NR & $\mathrm{P}$ & $\mathrm{P}$ & $\mathrm{R}$ & $\mathrm{R}$ & $\mathrm{PC}$ & $\mathrm{PC}$ & $\mathrm{PC}$ \\
\hline High & High & NR & NR & NR & NR & NR & $\mathrm{P}$ & $\mathrm{P}$ & $\mathrm{R}$ & $\mathrm{R}$ & $\mathrm{PC}$ & $\mathrm{PC}$ \\
\hline Well High & WH & NR & NR & NR & NR & NR & $\mathrm{P}$ & $\mathrm{P}$ & $\mathrm{R}$ & $\mathrm{R}$ & $\mathrm{PC}$ & $\mathrm{PC}$ \\
\hline Very High & $\mathrm{VH}$ & NR & NR & NR & $\mathrm{NR}$ & NR & NR & $\mathrm{P}$ & $\mathrm{P}$ & $\mathrm{R}$ & $\mathrm{R}$ & $\mathrm{PC}$ \\
\hline Maximum & Maximum & NR & NR & NR & NR & NR & NR & $\mathrm{P}$ & $\mathrm{P}$ & $\mathrm{R}$ & $\mathrm{R}$ & PC \\
\hline
\end{tabular}

software, and communitarians. The IDE used in Arduino has open source code, both for handling and for use (libraries). Arduino also has hardware design information (schematics, PCB layouts, etc.), available under Creative Commons licenses.

The choice for the use of the platform is due to the advantages in using it, such as: (i) compact, low power consumption hardware, able to process the Fuzzy logic controller, eliminating the use of computers; (ii) it is open source hardware and software, enabling a Developer's full autonomy in their use; (iii) low cost; among others;

The $\mathrm{C}++$ language was chosen because Arduino uses a layer of software implemented on the board, which is a bootloader and a user-friendly interface on a computer that uses language Processing [4] based on $\mathrm{C} / \mathrm{C}++$.

Through this bootloader, there is no need for the use of programmers for the chip - in this case the AVR family of the ATMEL manufacturer - further facilitating its use, since it does not require additional hardware or compilers. In this development environment, libraries are available that allow interfacing with other hardware, enabling the full development of simple or complex applications in any area (SOUZA, 2011).
Based on this, an algorithm was developed with the following characteristics:

Temperature and humidity vectors and rule maps for the application of fuzzy logic;

Temperature and humidity inputs, to carry out the simulation of the aeration system operation;

Mathematical functions, such as average between temperatures (assuming that there would be multiple thermometers collecting information), such as calculating the relevance of average temperatures and humidity (Defuzzification) and Fuzzy output, where the system's decision making is presented.

For the development of the algorithm, a membership function was implemented which is responsible for Defuzzification. For the input, it takes the value of the average temperature or humidity, and a vector with the set of Fuzzy control rules that was applied. Then this value is framed in an interval based on the rules map, and as output it returns a value that is used in the decision making system.

\section{RESULTS AND DISCUSSION}

In the operational tests of the developed system, operational simulations were realized using the Arduino software version 1.05. These simulations 


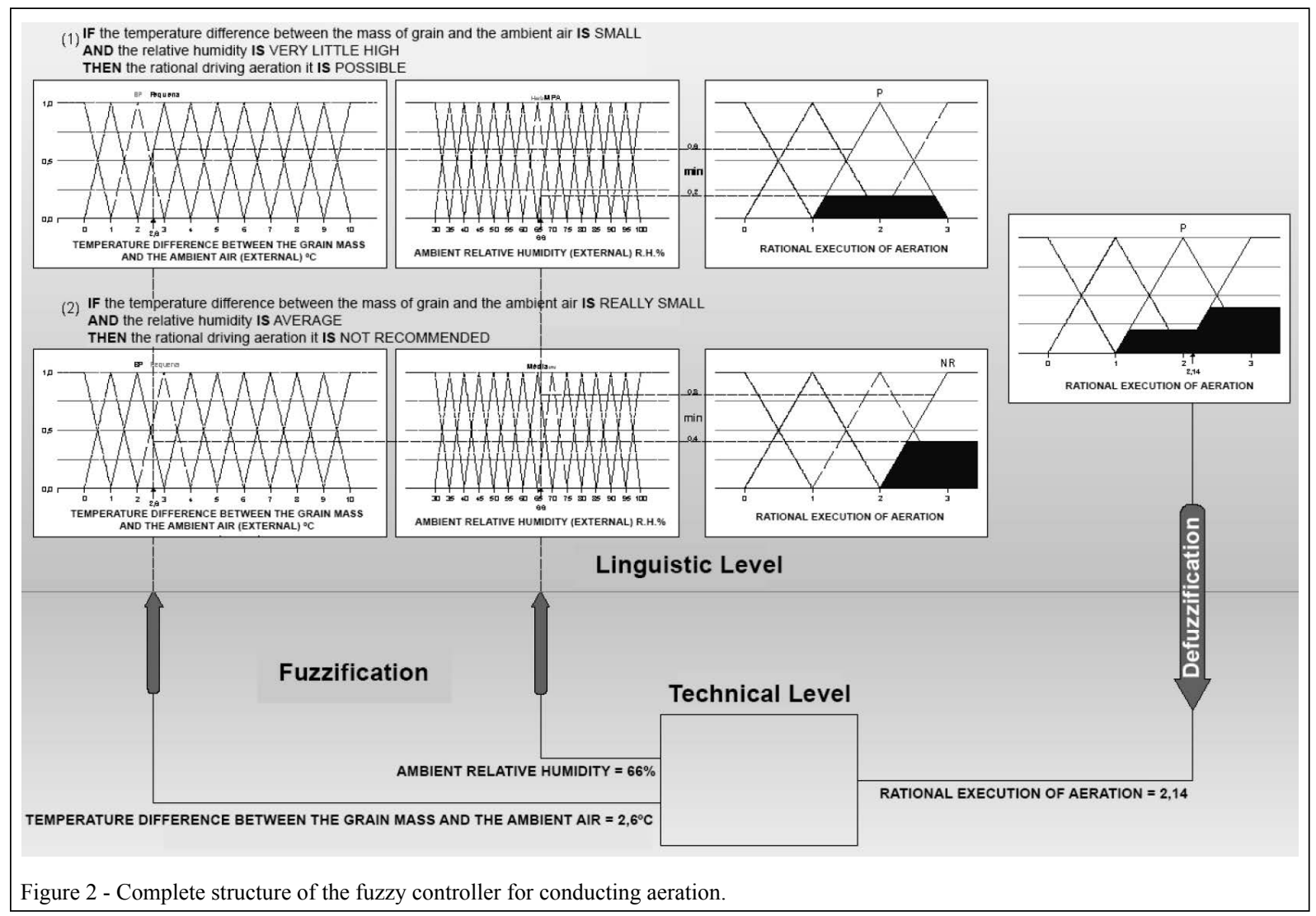

took place by inserting temperature and humidity values as input, obtaining the recommendation for the decision-making system as output.

In table 3 , one can see the results reported by Arduino, compared with those obtained directly on the chart presented by LASSERAN (1981). In the first case, the differentiation between the grain mass temperature and room temperature (TD) was $4.5^{\circ} \mathrm{C}$ and Relative Humidity (RH) was $48 \%$. In this case, based on the set of rules in this article, the system presented a Defuzzification value of 0.28 , which suggested that the aeration was possible taking certain precautions. In the second case, there was a TD of $3.3^{\circ} \mathrm{C}$, $\mathrm{RH}$ of $54 \%$ and Defuzzification 1.86 , where the system's suggestion was aeration recommended. In the third case, there was a TD $2.6^{\circ} \mathrm{C}$, RH of $66 \%$ and Defuzzification 2.14, and the system's suggestion was aeration Possible. In the fourth case there was a TD of $1.0^{\circ} \mathrm{C}, \mathrm{RH}$ of $75 \%$ and Deffuzificação of 3.00 , with a system suggestion of Aeration Not Recommended.

Reading the process variables (temperature and humidity) of the simulation conducted using the Arduino platform and the comparisons made, equivalents and reliable results can be reported. So, the application of this technology in a real environment will not require the intervention of an operator on-site to acquire these input data, which makes the system highly dynamic.

\section{CONCLUSION}

The control technique, using fuzzy logic based on the CRUZ et al. (2002) mathematical model, and applied to a system based on Arduino for the support of decision making during grain aeration, proved to be effective with simulated input data, making it possible to manage the aeration rationally, controlling the necessary aeration time for appropriate storage conditions.

The use of the aeration technique, along with fuzzy logic-based systems, and combined with free hardware based on the Arduino platform, proved to be effective for dynamic aeration control, maximizing the maintenance of stored grain quality, and with great potential for future projects. 
Table 3 - Results reported by Arduino, compared with those obtained directly on the chart presented by Lasseran (1981).

\begin{tabular}{|c|c|c|c|c|c|}
\hline \multirow{2}{*}{ Situation } & \multicolumn{2}{|c|}{--------------Environmental Conditions------------ } & \multirow{2}{*}{$\begin{array}{c}\text { Chart Lasseran (1981) } \\
\text { Conclusion }\end{array}$} & \multicolumn{2}{|c|}{$\begin{array}{l}\text { Analysis of the results presented by the Arduino } \\
\text { control system }\end{array}$} \\
\hline & $\mathrm{TD}=$ Tgrain - Tair $^{\circ} \mathrm{C}$ & $\begin{array}{l}\text { Relative Humidity } \\
(\mathrm{RH} \%)\end{array}$ & & Conclusion & Defuzzification \\
\hline 1 & 4.5 & 48 & Possible Care & Possible Care & 0.28 \\
\hline 2 & 3.3 & 54 & Recommended & Recommended & 1.86 \\
\hline 3 & 2.6 & 66 & Possible & Possible & 2.14 \\
\hline 4 & 1.0 & 75 & Not Recommended & Not Recommended & 3.00 \\
\hline
\end{tabular}

\section{ACKNOWLEDGEMENTS}

To Conselho Nacional de Desenvolvimento Científico e Tecnológico $(\mathrm{CNPq})$ for the financial support used in this study.

\section{REFERENCES}

CLOUD, H.A.; MOREY, R.V. Management of stored grain with aeration. St. Paul: University of Minnesota, 1979. 8p.

CLOUD, H.A.; MOREY, R.V. Management of stored grain with aeration. University of Minnesota. Extension service. 1991. Online. Available from: <http://www. extension.umn.edu/ distribution/cropsystems $>$. Accessed: Jan. 10, 2014.

CRUZ, L. F et al. Fuzzy model to calculate aeration time in vertical silos to reduce electric energy consume. In: Procedings of the 4th Encontro de Energia no Meio Rural. 2002, Campinas (SP) [online]. Available from: <http://www.proceedings.scielo.br/ scielo.php?script $=$ sci_arttext\&pid=MSC00000000220020002000 27\&lng=en\&nrm=iso>. Accessed: Dec. 15, 2013.

HUNG, B.N. et al. Integration of desiccant tray unit with internal cooling for aeration of paddy silo in humid tropical climate. Biosystems Engineering. v.102, n.1, p.75-82, 2009. Available from: $\quad<$ http://dx.doi.org/10.1016/j.biosystemseng.2008.09.029>. Accessed: Dec. 15, 2013. doi: 10.1016/j.biosystemseng.2008.09.029.

LASSERAN, J.C. Aeração de grãos. Viçosa: CENTREINAR, 1981. 131p.
LOPES, D.C. et al. Aeration simulation of stored grain under variable air ambient conditions. Postharvest Biology and Technology. v.42, n.1, p.115-120, 2006. Available from: <http://dx.doi.org/10.1016/j. postharvbio.2006.05.007>. Accessed: Dec. 15, 2013. doi: 10.1016/j.postharvbio.2006.05.007.

NAVARRO, S.; NOYES, R.T. The mechanics and physics of modern grain aeration management. Denver: CRC, LLC, 2001. 673p.

OXER, J.; BLEMING, H. Pratical Arduino. Cool projects for open source hardware. Springer-Verlag. Nova Iorque: SpringerVerlag, 2009. 456p.

SILVA, J.S. Pré-processamento de produtos agrícolas. Juiz de Fora: Instituto Maria, 1995. 500p.

SOUZA, A.R. de et al. The Arduino board: a low cost option for physics experiments assisted by PC. Revista Brasileira de Ensino de Física, v.33, n.1, p.01-05, 2011. Available from: <http:// dx.doi.org/10.1590/S1806-11172011000100026>. Accessed: Dec. 05, 2013. doi: 10.1590/S1806-11172011000100026.

WEBER, E.A. Excelência em beneficiamento e armazenagem de grãos. Canoas: Salles, 2005. 586p.

ZADEH, L.A. Fuzzy Sets. Information and Control, v.8, p.338353, 1965. Available from: <http://dx.doi.org/10.1016/S00199958(65)90241-X>. Accessed: Dec. 12, 2013. doi: 10.1016/ S0019-9958(65)90241-X. 